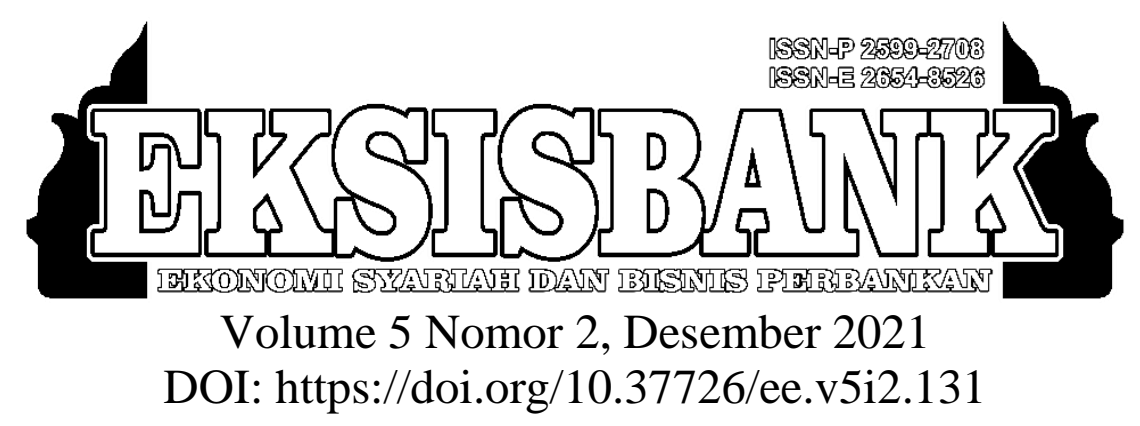

\title{
Analisis Sistem Pembiayaan Akad Qardhul Hasan Di BMT Al-Amanah Cabang Subang
}

\author{
Meinizar Arini Putri ${ }^{1}$, Siti Hapipah ${ }^{2}$, Siti Rohmat ${ }^{3}$ \\ 1,2,3 Sekolah Tinggi Ilmu Ekonomi Syariah (STIES) Indonesia Purwakarta \\ Jalan Veteran No. 150-152 Ciseureuh Purwakarta \\ ${ }^{1}$ meinizararini@gmail.com \\ ${ }^{2}$ sitihapipah@sties-purwakarta.ac.id \\ ${ }^{3}$ sitirohmat@sties-purwakarta.ac.id
}

\begin{abstract}
ABSTRAK
Pembiayaan Qardhul Hasan di BMT Al-Amanah Subang tidak dilakukan survei kembali, karena survey qardhul hasan sudah dilakukan pada awal anggota melakukan pembiayaan sebelumnya seperti pembiayaan Mudharabah, Murabahah, Musyarakah, dan Rahn, karena pembiayaan Qarhdul Hasan ini sifat nya koversi dari akad sebelumnya. Pembiayaan Qardhul Hasan memiliki ketegori tertentu terhadap pembiayaan kebutuhan anggota seperti biaya pendidikan, biaya pengobatan, dan sebagainya. Tujuan penelitian ini adalah untuk mengetahui syarat dan ketentuan pembiayaan Qardhul Hasan di BMT Al-Amanah Cabang Subang; Untuk mengetahui sistem pembiayaan Akad Qardhul Hasan di BMT Al-Amanah Cabang Subang; dan Untuk mengetahui manfaat Akad Qardhul Hasan bagi anggota dan pengelola BMT AlAmanah Cabang Subang. Hasil penelitian ini 1). Syarat dan ketentuan pembiayaan Qardhul Hasan di BMT Al-Amanah Cabang Subang tidak menggunakan jaminan dengan syarat harus menjadi anggota BMT Al-Amanah, serta anggota tidak mampu lagi untuk membayar angsuran pembiayaan akad sebelumnya yang telah jatuh tempo; 2. Sistem Pembiayaan Qardhul Hasan di BMT Al-Amanah Cabang Subang yaitu: a). Untuk anggota BMT Al-Amanah yang menjadi anggota aktif dengan mempunyai simpanan pokok dan simpanan wajib, b). Untuk anggota yang telah mempunyai pembiayaan, yang telah jatuh tempo, tetapi kesulitan untuk membayar angsuran pembiayaan, maka oleh BMT Al-Amanah di konversi akad menjadi Qardhul Hasan; 3). Manfaat Qardhul hasan bagi anggota dan pengelola yaitu: a). Bagi anggota yaitu Sangat Membantu anggota yang sedang mengalami kesulitan untuk membayar angsuran dan sebagai sumber pinjaman yang bersifat non komersial / dana talang, b). Bagi pengelola yaitu Karena pembiayaan Qardhul Hasan bersifat sosial dan tolong menolong maka akan memberikan citra baik bagi BMT Al-Amanah Cabang Subang.
\end{abstract}


Kata kunci- Syarat dan Ketentuan, Akad Qardhul Hasan, Sistem Qardhul Hasan, Manfaat Qardhul Hasan.

\begin{abstract}
The Qardhul Hasan financing at BMT Al-Amanah Subang was not surveyed again, because the Qardhul Hasan survey had been carried out at the beginning of the members doing previous financing such as Mudharabah, Murabahah, Musyarakah, and Rahn financing, because Qarhdul Hasan financing is a conversion from the previous contract. Qardhul Hasan financing has certain categories for financing the needs of members such as education costs, medical expenses, and so on. The purpose of this study was to determine the terms and conditions of financing Qardhul Hasan at BMT Al-Amanah Subang Branch; To find out the Qardhul Hasan contract financing system at BMT Al-Amanah Subang Branch; and To find out the benefits of the Qardhul Hasan Agreement for members and managers of BMT Al-Amanah Subang Branch. The results of this study 1). The terms and conditions of Qardhul Hasan financing at BMT Al-Amanah Subang Branch do not use collateral on the condition that they must become members of BMT Al-Amanah, and members are no longer able to pay installments of previous contract financing that have matured; 2. Qardhul Hasan Financing System at BMT Al-Amanah Subang Branch, namely: a). For members of BMT Al-Amanah who are active members by having principal and mandatory savings, b). For members who already have financing, which is past due, but have difficulty paying the financing installments, BMT Al-Amanah converts the contract into Qardhul Hasan; 3). The benefits of Qardhul hasan for members and managers are: a). For members, it is very helpful for members who are having difficulty paying installments and as a source of non-commercial loans / bailout funds, b). For managers, namely because Qardhul Hasan financing is social and please help it will give a good image for BMT Al-Amanah Subang Branch.
\end{abstract}

Keywords - Terms and Conditions, Qardhul Hasan Contract, Qardhul Hasan System, Qardhul Hasan Benefits.

\section{PENDAHULUAN}

Penduduk Indonesia sebagian besar beragama Islam yang dalam melakukan kegiatan sehari-hari sudah seharusnya menggunakan syariat Islam sebagai landasan dalam rangka memenuhi kesejahteraan bersama, baik untuk diri sendiri maupun orang lain. Islam memerintahkan seorang muslim untuk bekerja sekuat tenaga dalam mencari rezeki yang halal (Qadir 2001). Untuk memenuhi kebutuhan seseorang maupun keluarganya, seseorang dapat meminjam kepada orang lain. Jika kebutuhan itu untuk modal usaha, seseorang dapat meminjam kepada lembaga formal maupun non formal. Dengan cara inilah seseorang akan mendapatkan penghasilan untuk memenuhi kebutuhannya. Dukungan regulasi dan fasilitas pemerintah sangat diperlukan bagi tumbuh kembangnya usaha rakyat berbasis Syariah (Amalia 2011).

Banyak bank-bank Syariah yang tersebar diseluruh Indonesia, namun pada kenyataannya belum mampu menyentuh masyarakat kalangan menengah kebawah. Masyarakat kalangan menengah kebawah pada umumnya nyaris tidak tersentuh dan tidak dianggap memiliki potensi dana oleh Lembaga Keuangan Formal, sehingga menyebabkan laju pertumbuhan ekonomi terhambat. Faktanya mayoritas masyarakat kalangan menengah kebawah banyak terjebak 
meminjam kepada rentenir (Muhammad 2005).

Keberhasilan perbankan Syariah di Indonesia tidak bisa lepas dengan adanya Lembaga Keuangan Mikro Syariah (LKMS). Lembaga Keuangan Mikro Syariah merupakan suatu model penyediaan jasa keuangan bagi masyarakat yang memiliki usaha pada sektor paling kecil yang tidak dapat mengakses dunia perbankan karena berbagai macama keterbatasan (Sriyana and Raya 2013). Lembaga Keuangan yang mampu menjangkau semua lapisan masyarakat antara lain, Koperasi Simpan Pinjam Syariah (KSPS), Baitul Maal wat Tamwil (BMT), Bank Perkreditan Rakyat Syariah (BPRS), Perum Pegadaian dan lain sebagainya. Lembaga pelayanan pembiayaan tersebut yang ideal harus mencerminkan prinsip sosial dan ekonomi. Prinsip sosial ditujukan dengan adanya kepedulian lembaga tersebut dengan masyarakat di lingkungannya, sedangkan prinsip ekonomi (efektif dan efisien) menjadi motor penggerak roda bisnis lembaga tersebut. Tuntutan pelayanan dalam pemberian pembiayaan harus disikapi sebagai sebuah fasilitas kemudahan bagi masyarakat untuk meningkatkan produktivitas usahanya (Muhammad 2004).

Kehadiran BMT adalah solusi bagi kelompok ekonomi masyarakat yang membutuhkan dana bagi pengembangan usahanya. BMT merupakan lembaga ekonomi masyarakat yang berupaya mengembangkan usaha produktif dan investasi dalam rangka meningkatkan kegiatan usahanya dengan berdasarkan prinsip syariah dan prinsip operasional. Dilihat dari namanya Baitul Maal berarti lembaga sosial sejenis BAZIS (Badan Amil Zakat sedangkan Baitul Tamwil berarti lembaga bisnis. BMT sebagai lembaga bisnis lebih mengembangkan usahanya pada sektor keuangan, yakni simpan-pinjam. Usaha ini sama seperti usaha perbankan yakni menghimpun dana nasabah atau dalam ruang lingkup BMT biasanya dikenal dengan sebutan anggota dan calon anggota serta menyalurkan kepada sektor ekonomi yang halal dan menguntungkan (Arumastuti 2016).

Produk pembiayaan di BMT Al-Amanah Cabang Subang meliputi pembiayaan Qardhul Hasan. Pelayanan pembiayaan diberikan kepada seluruh anggota biasa atau anggota luar biasa yang membutuhkan penambahan modal usaha dengan berdasarkan prinsip bagi hasil, jual beli, jasa atau pinjam meminjam (BMT Al-Amanah Subang 2019).

Salah satu produk yang didalamnya terkandung misi sosial yaitu Akad Qardhul Hasan. Misi sosial yang dimaksud yaitu dengan adanya midi sosial kemasyarakatan ini akan meningkatkan citra baik dan meningkatkan loyalitas masyarakat terhadap BMT. Akad Qardh merupakan akad yang memfasilitasi transaksi peminjaman sejumlah dana tanpa adanya bembebanan bunga atas dana yang dipinjam oleh anggota. Transaksi Qardh pada dasarnya merupakan transaksi yang bersifat sosial karena tidak diikuti dengan pengambilan keuntungan dari dana yang dipinjamkan (Administrasi 2019).

Pembiayaan Qardhul Hasan ini disamping pemberian bantuan untuk modal usaha dapat juga diberikan kepada anggota yang memerlukan dana bukan untuk usaha lelainkan untuk kegiatan yang tidak menghasilkan misalnya untuk biaya berobat, biaya anak sekolah dan kebutuhan lainnya sesuai kebijakan pengurus, dan dana untuk kegiatan sosial anggota ini diperoleh dari dana zakat, infak dan sedekah yang dihimpun oleh pengurus sampai akhir tahun 2018 ini sebesar Rp. 15.135.376,68 kemudian disalurkan kepada panti asuhan dan mustahiq. Akad Qardhul Hasan di BMT Al-amanah Cabang Subang lebih banyak digunakan oleh anggota BMT yang memiliki kesulitan untuk 
membayar sisa tunggakannya, oleh sebab itu terjadi konferensi pemindahan akad.

Teori yang digunakan oleh peneliti sebelumnya tentang Qardhul Hasan yaitu Menurut Heru Sulistyo meneliti tentang model Pembiayaan Pedagang Kaki Lima (PKL) melalui Qardhul Hasan. Hasil penelitian menunjukan bahwa tingkat kemacetan Pembiayaan Qardhul Hasan sangat kecil dan mayoritas PKL merasakan adanya peningkatan pendapatan dan tingkat kesejahteraan mereka. Beberapa lembaga seperti Bank Syariah, BPR Syariah, BMT, Laznas dan Bazda Kota Semarang dan Bazda Provinsi Jawa Tengah sudah menyalurkan pembiayaan tersebut namun masih dalam porsi yang kecil" (Sulistyo and Hakim 2013).

Pengertian Qardhul Hasan menurut beberapa sumber sebagai berikut :

1. Qardh merupakan pinjaman kebijakan/ lunak tnpa imbalan, biasanya untuk pembelian barang-barang yang dapat diperkirakan dan diganti sesuai berat, ukuran dan jumlahnya (Ascarya 2011).

2. Qardh merupakan pemberian harta kepada orang lain yang dapat ditagih atau diminta kembali sesuai dengan jumlah uang yang dipinjamkan, tanpa adanya tambahan atau imbalan yang diminta oleh Bank Syariah/Lembaga Keuangan Syariah (Ismail 2017).

3. Qardh adalah harta yang diberikan oleh pemberi utang (Muqridh) kepada penerima utang (Muqtaridh) untuk kemudian dikembalikan kepadanya (Muqrid) seperti yang diterima, ketika ia telah mampu membayarnya (Muslich 2010).

4. Dalam leteratur fiqih klasik Qardh dikategorikan dalam "Aqad ta'awun" atau akad saling membantu dan bukan transaksi komersial (Antonio 2001).

Dari pengertian diatas penulis menyimpulkan bahwa yang dimaksud dengan Qardhul Hasan adalah sebuah produk dimana produk ini merupakan produk ta'awun (tolong menolong) dimana dana ini bersumber dari zakat, infaq dan sedakah yang bersifat sosialis dan bukan untuk kebutuhan komsumtif semata, tetapi untuk kebutuhan mendesak seperti biaya pengobatan, pendidikan dan lain-lain.

Menurut Dedi Riswandi melakukan penelitian mengenai pembiayaan Qardhul Hasan di Bank Syariah Mandiri (BSM) Kota Mataram. Hasil dari penelitian ini adalah Pelaksanaan pembiayaan Qardhul Hasan di BSM Cabang Mataram diaplikasikan dalam program yang disebut dengan Program Mitra Umat. Secara garis besar program ini terbagi dalam kegiatan pemberdayaan ekonomi (diwujudkan dalam bentuk pemberian pinjaman Qardhul Hasan berupa modal usaha atau investasi dan konsumtif) dan kegiatan sosial (sumbangan). Dalam proses pelaksanaan pemberian pembiayaan ini BSM Cabang Mataram banyak memberikan kemudahan-kemudahan terutama dalam proses pengajuan dan pembayaran angsuran, sehingga nasabah merasa nyaman dengan pelayanan pembiayaan ini. Akan tetapi, pembiayaan ini hanya diberikan kepada calon nasabah yang mempunyai kepercayaan yang tinggi serta kemauan dan kemampuan. Pelaksanaan pembiayaan Qardhul Hasan di BSM kota Mataram sudah sesuai dengan syariah, ketentuan dan persyaratan DSN. Kontribusi dana Qardhul Hasan bagi Usaha Mikro nasabah adalah adanya peningkatan pendapatan yang rata-ratanya adalah sekitar $66 \%$. Dengan adanya peningkatan pendapatan usaha sebesar $66 \%$ berarti pembiayaan Qardhul Hasan telah memberikan kontribusi sebesar $18 \%$ kepada masyarakat miskin untuk berada di atas batas garis kemiskinan. Selain pendapatan nasabah responden mengalami peningkatan, modal usaha juga mengalami peningkatan (Riswandi 2015). 
Dari beberapa penelitian yang telah disebutkan di atas, dapat disimpulkan bahwa belum ada yang secara rinci bahkan langsung mengarah kepada Analisis Sistem Pembiayaan Akad Qardhul Hasan di BMT Al-Amanah Cabang Subang.

Berdasarkan latar belakang yang telah diuraikan diatas, tujuan penelitian ini adalah untuk mengetahui syarat dan ketentuan pembiayaan Qardhul Hasan di BMT AlAmanah Cabang Subang; Untuk mengetahui sistem pembiayaan Akad Qardhul Hasan di BMT Al-Amanah Cabang Subang; dan Untuk mengetahui manfaat Akad Qardhul Hasan bagi anggota dan pengelola BMT Al-Amanah Cabang Subang.

\section{A. Pengertian Qardh \\ II. TINJAUAN PUSTAKA}

Secara bahasa qardh berarti potongan, sedangkan pengertian secara terminologi berarti pemberian harta kepada orang lain yang dapat diminta kembali dengan jumlah yang sama atau dengan kata lain meminjamkan tanpa mengharapkan imbalan atau tambahan (Budiman 2013). Sedangkan, qardh al-hasan berasal dari bahasa arab yaitu "ihsan" yang artinya kebaikan kepada orang lain. Qardh al-hasan merupakan jenis pinjaman yang diberikan kepada pihak yang sangat memerlukan untuk jangka waktu tertentu tanpa harus membayar bunga atau keuntungan (Faujiah 2020). Penerima pinjaman hanya berkewajiban melunasi jumlah pinjaman pokok tanpa diharuskan memberikan tambahan apapun. Namun, apabila penerima pinjaman boleh saja atas kebijakannya sendiri membayar lebih dari uang yang dipinjamnya sebagai tanda terima kasih kepada pemberi pinjaman. Tetapi hal tersebut tidak boleh diperjanjikan sebelumnya di muka.

Qardh hasan adalah perjanjian qardh (pinjaman) yang khusus untuk tujuan sosial.
Qard hasan adalah suatu interest free financing. Kata hasan adalah kata Bahasa Arab ialah ihsan yang berarti kebaikan kepada orang lain (Arief 2012). Qard hasan atau qardhul hasan berarti beneficial loon atau benevolent loan, yaitu pinjaman yang diberikan kepada pihak yang sangat memerlukan untuk jangka waktu tertentu tanpa harus membayar bunga/keuntungan. Dan penerima qard hasan hanya diharuskan untuk melunasi jumlah pinjaman semula tanpa diharuskan memberikan tambahan apa pun.

Qardhul hasan adalah pinjaman tanpa adanya imbalan yang memungkinkan peminjam untuk menggunakan dana tersebut selama jangka waktu tertentu dan mengembalikan dalam jumlah yang sama pada akhir periode yang disepakati (Qardhawi 1993). Dari beberapa devinisi diatas, beberapa pakar ekonomi mendevinisikan tentang akad qardhul hasan, salah satu diantaranya :

Menurut Sri Nurhayati dan Wasilah qardhul hasan adalah pinjaman tanpa dikenakan biaya (hanya wajib membayar sebesar pokok hutangnya), pinjaman uang seperti inilah yang sesuai dengan ketentuan Syariah (tidak ada riba), karena kalua meminjamkan uang maka ia tidak boleh meminta pengembalian yang lebih besar dari pinjaman yang diberikan (Muhamad Bisri Mustofa and Mifta Khatul Khoir 2019). Sedangkan Ahmad Ifham Sholihin dalam buku pintar ekonomi syariah menyebutnya sebagai qardh al-hasan atau pinjaman kebijakan adalah yang pertama, pinjaman dengan kewajiban pengembalian pinjaman pokoknya saja, tanpa imbalan apa pun. Yang kedua, suatu akad pinjammeminjam dengan ketentuan pihak yang menerima pinjaman tidak wajib mengembalikan dana apabila terjadi force majeure.

Dapat disimpulkan qardhul hasan adalah perjanjian hutang dengan syarat bahwa 
penerima pinjaman hanya membayar pokok hutangnya saja tanpa ada tambahan apapun ketika mengembalikan/ membayarkan hutang tersebut.

Dalam ekonomi/keuangan syariah, qardhul hasan adalah pinjaman yang tidak mengambil manfaat (keuntungan) apapun namun tetap ditentukan untuk dibayarkan kembali. Produk/ skema ini merupakan salah satu produk/skema sistem keuangan Syariah yang sangat penting dalam mendukung pemulihan atau menopang perekonomian.

\section{B. Dasar Hukum Qardh}

QS. al-Baqarah : 282

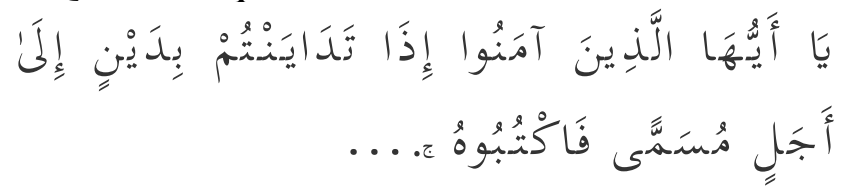

"Hai orang-orang yang beriman, apabila kamu bermu'amalah tidak secara tunai untuk waktu yang ditentukan, hendaklah kamu menuliskannya ..." (Subarkah et al. 2012).

Korelasi potongan ayat QS. al-Baqarah : 282, bahwa qardhul hasan bagian dari pembiayaan atau muamalah yang tidak tunai, dimana transaksi yang tidak tunai biasanya muncul permasalahan dikemudian hari, seperti lupa jatuh tempo pembiayaan, lupa nominal pembiayan, dll. Maka dari itu, pembiayan Qardhul hasan harus ditulis (slip atau kontrak pencairan) sebagai bukti dan menjadi salah satu solusi saat terjadinya sengketa diantara kedua belah pihak.

\section{QS. Al-Ma'idah : 1}

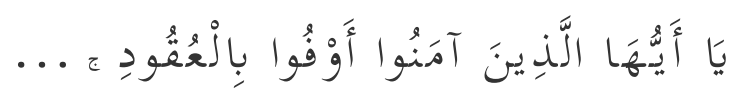

"Hai orang-orang yang beriman, penuhilah aqad-aqad itu ..." (Subarkah et al. 2012)

Korelasi potongan QS. Al-Ma'idah : 1 dengan qardh, karena setiap akad-akad didalam Syariah mempunyai karakteristik dan fungsinya masing-masing, maka tidak bisa sembarangan menggunakan akad-akad
Syariah, seperti pembiayan murabahah syarat dan ketentuannya digunakan pembiayaan prinsip jual beli; pembiayaan Ijarah, syarat dan ketentuannya digunakan untuk pembiayaan sewa menyewa. Termasuk pembiyaan qardhul hasan mempunyai syarat dan ketentuannya seperti pembiayaan untuk biaya Pendidikan, biaya berobat, biaya pembangunan pesantren, dll. Jika akad yang disepakati menggunakan akad Qardhul hasan, maka syarat dan ketentuan atau syarat dan rukunnya harus yang berhubungan dengan qardhul hasan. Jangan kemudian dibalik atau diputar seperti akad yang disepakati menggunakan akad qardhul hasan, tapi syarat dan ketentuan yang digunakan menggunakan akad murabahah, tidak akan nyambung, karena beda akad beda peruntukannya.

QS. al-Baqarah : 280

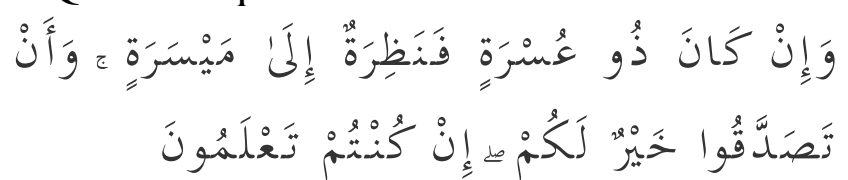

"Dan jika (orang yang berhutang itu) dalam kesukaran, maka berilah tangguh sampai dia berkelapangan. Dan menyedekahkan (sebagian atau semua utang) itu, lebih baik bagimu, jika kamu mengetahui." (Enang 2010).

\section{Shahih Muslim Nomor 4677}

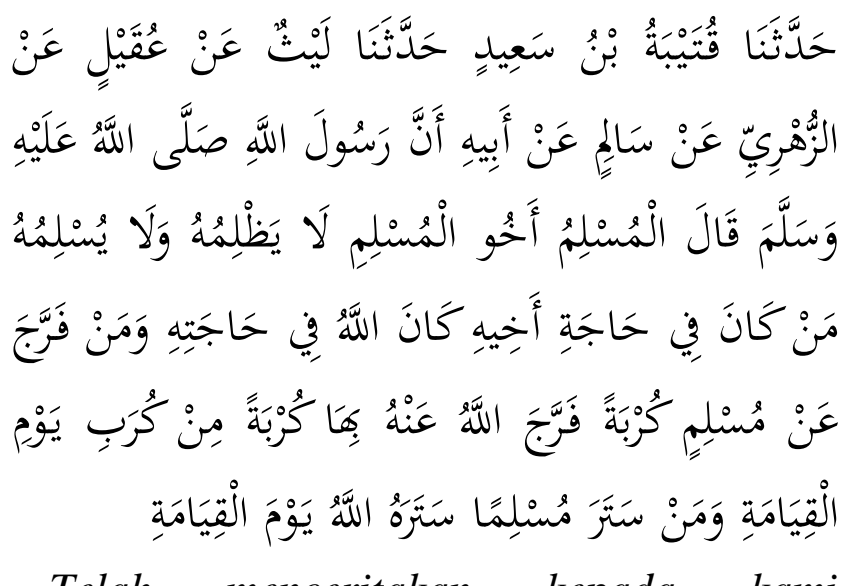

Telah menceritakan kepada kami [Qutaibah bin Sa'id]; Telah menceritakan

EKSISBANK (Ekonomi Syariah dan Bisnis Perbankan), Volume 5, Nomor 2, Desember 2021 
kepada kami [Laits] dari ['Uqail] dari [Az Zuhri] dari [Salim] dari [Bapaknya] bahwa Rasulullah shallallahu 'alaihi wasallam bersabda: "Seorang muslim dengan muslim yang lain adalah bersaudara. Ia tidak boleh berbuat zhalim dan aniaya kepada saudaranya yang muslim. Barang siapa yang membantu kebutuhan saudaranya, maka Allah akan memenuhi kebutuhannya. Barang siapa membebaskan seorang muslim dari suatu kesulitan, maka Allah akan membebaskannya dari kesulitan pada hari kiamat. Dan barang siapa menutupi aib seorang muslim, maka Allah akan menutupi aibnya pada hari kiamat kelak." (Hajjaj, n.d.).

Shahih Bukhari Nomor 2262

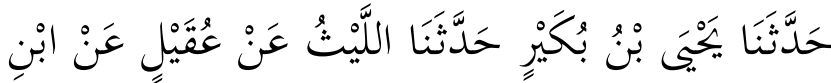
شِهَابِ أَنَّ سَالِِما أَخْبَرَهُ أَنَّ عَبْدَ اللَّهِ بْنَ عُمَرَ رَضِيَ اللَّهُ

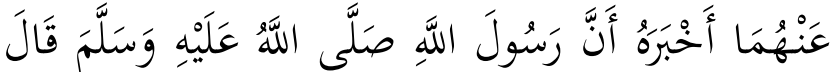

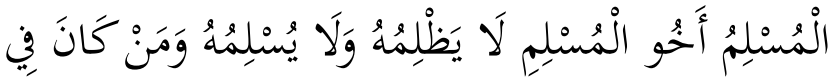

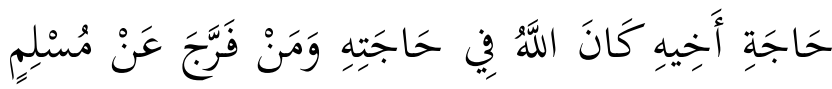

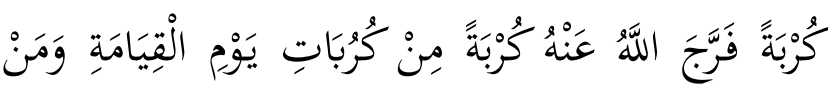
سَتَرَ مُسْلِمًا سَتَرَهُ اللَّهُ يَوْمَ الْقِيَامَةِ.

Telah menceritakan kepada kami [Yahya bin Bukair] telah menceritakan kepada kami [Al Laits] dari ['Uqail] dari [Ibnu Syihab] bahwa [Salim] mengabarkannya bahwa ['Abdullah bin 'Umar radliallahu 'anhuma] mengabarkannya bahwa Rasulullah shallallahu 'alaihi wasallam bersabda: "Seorang muslim adalah saudara bagi muslim lainnya, dia tidak menzhaliminya dan tidak membiarkannya untuk disakiti. Siapa yang membantu kebutuhan saudaranya maka Allah akan membantu kebutuhannya. Siapa yang menghilangkan satu kesusahan seorang muslim, maka Allah menghilangkan satu kesusahan baginya dari kesusahan-kesusahan hari qiyamat. Dan siapa yang menutupi (aib) seorang muslim maka Allah akan menutup aibnya pada hari qiyamat" (Bukhari, n.d.).

Korelasi Shahih Muslim Nomor 4677 dan Shahih Bukhari Nomor 2262 dengan qardh, bahwa qardhul hasan bisa dijadikan sarana Lembaga keuangan Syariah khususnya BMT Al-Amanah Subang dalam membantu kesempitan, kesusahan, kegundahan umat. Insyaallah kalau niatnya ikhlas membantu kebutuhan nasabah, disisi lain BMT alAmanah Subang mendapatkan keuntungan di didunia, disisi lain pula BMT al-Amanah Subang mendapatkan pahala karena sudah membantu menghilangkan kesusahan nasabah.

Shahih Bukhari 2225

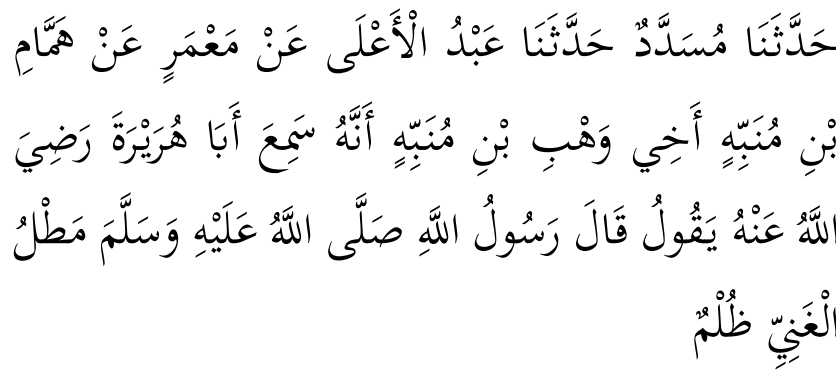

Telah menceritakan kepada kami [Musaddad] telah menceritakan kepada kami ['Abdul A'laa] dari [Ma'mar] dari [Hammam bin Munabbih, saudaranya Wahb bin Munabbih] bahwa dia mendengar [Abu Hurairah radliallahu 'anhu] berkata; Nabi shallallahu 'alaihi wasallam bersabda: "Menunda pembayaran hutang bagi orang kaya adalah kezhaliman" (Bukhari, n.d.).

Shahih_Muslim Nomor 2924

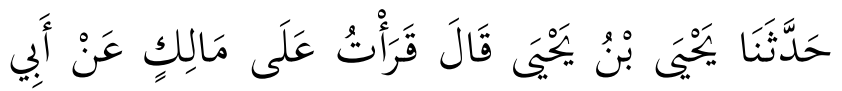

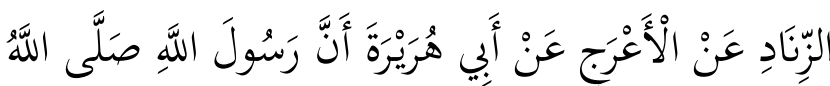

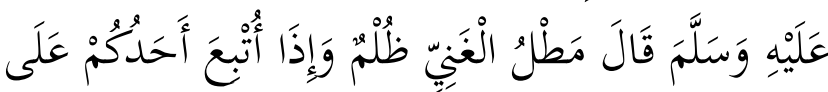

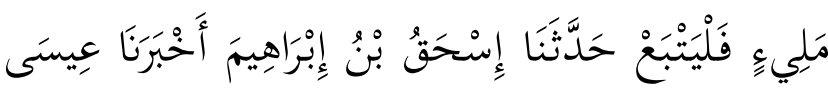

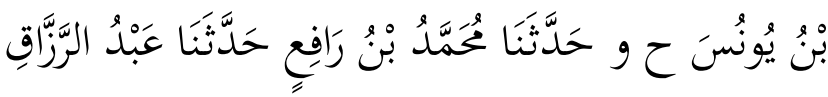

EKSISBANK (Ekonomi Syariah dan Bisnis Perbankan), Volume 5, Nomor 2, Desember 2021 


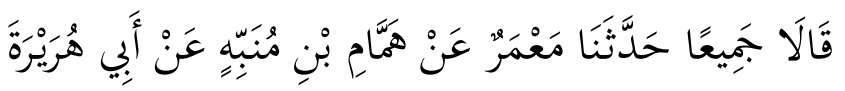

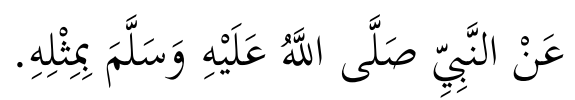

Telah menceritakan kepada kami [Yahya bin Yahya] dia berkata; saya baca di hadapan [Malik]; dari [Abu Zinnad] dari [Al A'raj] dari [Abu Hurairah], bahwa Rasulullah shallallahu 'alaihi wasallam bersabda: "Mengulur-ulur waktu pembayaran hutang bagi yang mampu adalah kezhaliman, dan jika piutang salah seorang dari kalian dialihkan kepada orang yang kaya, maka terimalah." Telah menceritakan kepada kami [Ishaq bin Ibrahim] telah mengabarkan kepada kami [Isa bin Yunus]. (dalam jalur lain disebutkan) Telah menceritakan kepada kami [Muhammad bin Rafi'] telah menceritakan kepada kami [Abdurrazaq] semuanya berkata; telah menceritakan kepada kami [Ma'mar] dari [Hammam bin Munabbih] dari [Abu Hurairah] dari Nabi shallallahu 'alaihi wasallam seperti hadis di atas." (Hajjaj, n.d.).

"Penundaan (pembayaran) yang dilakukan oleh orang mampu menghalalkan harga diri dan memberikan sanksi kepadanya" (HR. Nasa'i, Abu Daud, Ibn Majah, dan Ahmad)

"Orang yang terbaik di antara kamu adalah orang yang paling baik dalam pembayaran utangnya” (HR. Bukhari)

Kaidah Fiqih

"Setiap utang piutang yang mendatangkan manfaat (bagi yang berpiutang, muqridh) adalah riba."

\section{Rukun dan Syarat Qardh}

Setiap kegiatan bermuamalah sebagai umat muslim hendaknya memperhatikan rukun dan syarat yang sudah ditetapkan dalam hukum Islam, guna melengkapi suatu akad atau transaksi. Sehingga transaksi yang telah disepakati oleh kedua belah pihak dapat dinyatakan sah sesuai dengan hukum Islam. Adapun, rukun dan syarat qardh al-hasan antara lain (Muhamad Bisri Mustofa and Mifta Khatul Khoir 2019):

1. Orang yang meminjamkan

a. Berhak berbuat kebaikan

b.Manfaat dari barang yang dipinjamkan menjadi milik peminjam dan barang yang dipinjamkan menjadi milik yang meminjamkan.

2. Orang yang meminjam

a. Berhak mendapat kebaikan

b. Dapat dipercaya untuk menjaga barang tersebut

3. Barang yang dipinjamkan

a. Mempunyai manfaat yang dapat diambil oleh peminjam

b. Barang yang diambil manfaatnya tidak rusak karena pemakaian yang disetujui dalam perjanjian. Ulama hanafiyah berpendapat bahwa qard \} dipandang sah pada harta mitsil, yaitu sesuatu yang tidak terjadi perbedaan yang menyebabkan terjadinya perbedaan nilai. Diantara yang dibolehkan adalah benda-benda yang ditimbang, ditakar, atau dihitung.

\section{Ijab Qabul}

a. Kalimat mengutangkan Lafadz

b. Mu'ir (orang yang mengutangkan) merupakan pemilik barang tersebut, dan musta'ir (orang yang berhutang) harus baligh, dan berakal.

\section{Manfaat Adanya Qardh}

Qardhul Hasan memiliki beberapa manfaat bagi pihak-pihak yang menggunakannya. Adapun, manfaat dengan adanya qard alhasan antara lain:

1. Memungkinkan peminjam yang sedang dalam kesulitan mendesak untuk mendapat talangan jangka pendek. 
2.Pedagang kecil memperoleh bantuan dari pemberi pinjaman untuk mengembangkan usahanya, sehingga merupakan misi sosial bagi pihak yayasan dana sosial dalam membantu masyarakat miskin.

3. Adanya misi sosial-kemasyarakatan ini akan mengikat citra baik dan mengikatkan loyalitas masyarakat kepada yayasan dana sosial, karena dapat memberikan manfaat kepada masyarakat golongan miskin

\section{E. Perbandingan Penelitian Terdahulu}

Penelitian tentang Analisis Sistem Pembiayaan Akad Qardhul Hasan Di BMT sudah banyak dilakukan penelitian oleh peneliti sebelumnya, seperti penelitianpenelitian berikut ini:

1. Konsep Koperasi Bung Hatta Dalam Perspektif Ekonomi Syariah (Efendi and Bakhri 2018)

Penelitian ini dilatarbelakangi oleh belum banyaknya tokoh ekonomi Indonesia yang berkontribusi dalam perkembangan ekonomi syariah. Bung Hatta merupakan salah satu tokoh intelektual di bidang ekonomi yang mencurahkan idenya untuk kemajuan bangsa. Konsep koperasi merupakan bukti keprihatinan Bung Hatta akan kondisi ekonomi masyarakat Indonesia yang terjebak hutang oleh lintah darat. Konsep koperasi yang ditawarkan oleh Bung Hatta merupakan bentuk modern dari adat istiadat dan tradisi masyarakat Indonesia, yaitu semangat kolektivisme (gotong royong dan tolong menolong). Konsep tersebut diduga memiliki keterkaitan dengan konsep ekonomi syariah. Adapun yang menjadi perumusan masalah dalam penelitian ini adalah bagaimana konsep koperasi Bung Hatta dalam perspektif ekonomi syariah. Tujuan penelitian ini adalah untuk mengetahui konsep koperasi Bung Hatta dalam perspektif ekonomi syariah. Subjek penelitian ini adalah Bung Hatta. Sementara objek dalam penelitian ini adalah konsep koperasi Bung Hatta dalam perspektif ekonomi syariah. Jenis penelitian yang digunakan adalah jenis penelitian kepustakaan. Pendekatan yang digunakan melalui pendekatan filosofis dan komparatif. Teknik analisis data yang digunakan dalam penelitian ini yakni kualitaitif, yaitu dengan proses editing, klasifikasi, memberi kode, dan penafsiran. Penafsiran dilakukan dengan membandingkan konsep koperasi Bung Hatta dengan konsep ekonomi syariah. Hasil penelitian adalah terdapat persamaan konsep koperasi Bung Hatta dengan ekonomi syariah, yaitu pada akad, nilai-nilai dasar, prinsip tolong menolong, prinsip manfaat, prinsip mashlahah, fungsi, karakteristik, produksi, dan distribusi.

Perbedaan peneliti sebelumnya dengan peneliti saat ini adalah peneliti saat ini koperasi hanya dijadikan sebagai lokasi penelitian saja, bukan menkaji konsep koperasi Bung Hatta dalam pandangan ekonomi Syariah, melainkan mengkaji praktek Qardhul Hasan yang di praktekan di BMT Al-Amanah Cabang Subang.

2.Konsep Divisi Ekonomi Masjid Berbasis Teknologi Industri 4.0 (Ma'rifahYuliani 2019)

Dimasa lahirnya Islam, Masjid tidak berfungsi sebagai tempat ibadah sholat saja, melainkan sebagai tempat untuk urusan negara, politik, ekonomi atau lebih tepatnya disebut Masjid sebagai Pusat Ekonomi dan Peradaban Umat Islam. Ekonomi syariah tidak bisa hanya mengandalkan perbankan dan lembaga keuangan lainnya sebagai pusat ekonomi karena mereka diciptakan sebagai lembaga profit, tidak berorientasi untuk kepentingan umat. Masjid berfungsi sebagai tempat ibadah mnelainkan juga bisa digunakan sebagai pusat ekonomi mendirikan divisi ekonomi, dengan menyediakan sarana akad tabarru' (tolong menolong) yakni 
simpan pinjam menggunakan akad qardhul hasan, didukung teknologi revolusi industri 4.0 berbasis startup, masjid bisa sebagai pusat ekonomi yang hemat biaya yang berorientasi untuk kesejahteraan umat Muslim. Penelitian ini bertujuan mengembalikan masjid sebagai tempat pusat ekonomi, yakni bertemunya orang yang kuat secara ekonomi untuk membantu orang yang lemah, memberantas riba, menolong yang lemah ekonomi dengan menggunakan teknologi revolusi industri 4.0.

Perbedaan peneliti sebelumnya dengan peneliti saat ini adalah Masjid berfungsi sebagai tempat ibadah mnelainkan juga bisa digunakan sebagai pusat ekonomi mendirikan divisi ekonomi, dengan menyediakan sarana akad tabarru' (tolong menolong) yakni simpan pinjam menggunakan akad qardhul hasan, didukung teknologi revolusi industri 4.0 berbasis startup, masjid bisa sebagai pusat ekonomi yang hemat biaya yang berorientasi untuk kesejahteraan umat Muslim. Sedangkan pada peneliti saat ini koperasi yang menjadi lokasi penelitian dalam pengelolaannya masih belum di dukung dengan teknologi revolusi industry 4.0. yakni melainkan mengkaji praktek Qardhul Hasan yang di praktekan di BMT Al-Amanah Cabang Subang.

\section{Qardh al-Hasan dalam Perbankan Syariah:}

Konsep dan Implementasinya Berdasarkan

Prinsip Manfaat bagi Pemberdayaan Masyarakat (Purwadi 2011)

Qardh al-hasan adalah suatu sistem yang berkaitan dengan segala bentuk pinjaman tanpa imbalan yang berasaskan pada hukum al-qardh al hasan. Dalam literatur fikih klasik, konsep qardh al hasan dikategorikan dalam aqad tathawwi atau akad tolong menolong dan bukan transaksi komersial. Perjanjian ini dimasukkan ke dalam aqad tabarru', yaitu perjanjian transaksi nirlaba (not-for profit transaction). Apabila konsep ini diterapkan dalam Perbankan Islam maka kegunaan atau manfaat al-qardh al hasan dapat rasakan dan dinikmati oleh masyarakat melalui: Pertama, memahami konsep qardh al hasan secara tekstual dengan menggali nilai-nilai ilmiah dari ajaran Islam dan memperkaya persepsi masyarakat itu secara kontekstual dengan dimensi baru bahwa al-qardh al hasan merupakan suatu kekuatan yang memiliki dampak aktual terhadap kehidupan ekonomi umat Islam. Kedua, mengembangkan organisasi dan manajemen Perbankan Syariah secara profesional. Perorganisasian kegiatan al-qardh al hasan dilaksanakan melalui berbagai fungsi kelembagaan, seperti fungsi pengumpulan dan penyimpanan sumbersumber dana al-qardh al hasan, fungsi penyaluran, fungsi evaluasi, penelitian dan pengembanyan yang efektif.

Perbedaan peneliti sebelumnya dengan peneliti saat ini adalah peneliti terdahulu mengimplementasikan akad Qardhul Hasan pada Lembaga perbankan Syariah bukan pada Lembaga koperasi, Sedangkan pada peneliti saat ini lokasi penelitian merupakan lembaga koperasi perorangan.

4. Baitul Maal Wa Tamwil Sebagai Lembaga Keuangan Mikro Syariah Pemberdaya Ekonomi Umat (Konsep dan Teori) (Solekha et al. 2021)

Tujuan penelitian untuk menggali lebih dalam konsep dan teori Baitul Maal Wa Tamwil, karena dilatarbelakangi oleh kenyataan yang terjadi di lingkungan bahwa BMT telah menunjukkan keberhasilannya yang telah tersebar luas hampir di seluruh wilayah Indonesia, terbukti di Tahun 2016 mencapai 6000 unit BMT dan menemukan prospek yang baik. Jenis penelitian ini adalah kualitatif, didukung oleh data yang diambil secara sekunder dengan menggunakan studi kepustakaan. Untuk menunjang penelitian, penulis mengolah data menggunakan Ms. Excel. BMT adalah lembaga keuangan mikro 
syariah sebagai lembaga swadaya masyarakat yang menghimpun dan mengelola dana menurut prinsip syariah dalam rangka mencapai tujuan ekonomi keuangan dan kemanusiaan atau untuk mencapai mashlahah. BMT tidak hanya fokus pada kegiatan keuangan tetapi juga kegiatan kebajikan sosial. BMT mengacu pada sumber otoritatif Islam, UU No. 25 tahun 1992 tentang perkoperasian dan fatwa DSN-MUI. Sumber pembiayaan berasal dari pelanggan dan hasil pendapatan operasional. Dana nasabah kemudian dikelola dengan menggunakan pembiayaan dan akad syariah, keuntungannya dikenal dengan bagi hasil. BMT harus selalu melakukan evaluasi agar sistem operasional dan sumber dayanya lebih baik dan terus melakukan sosialisasi kepada masyarakat.

Perbedaan peneliti sebelumnya dengan peneliti saat ini adalah peneliti terdahulu meneliti Teori dan Konsep Lembaga BMT yang dianggap telah sukses menunjukkan keberhasilannya yang telah tersebar luas hampir di seluruh wilayah Indonesia, terbukti di Tahun 2016 mencapai 6000 unit BMT dan menemukan prospek yang baik. Sedangkan pada peneliti saat ini menganalisis sistem pembiayaan akad qardhul hasan yang di praktekan pada Lembaga keuangan BMT AlAmanah Cabang Subang.

\section{Praktek Akad Qardhul Hasan Pada Bank Wakaf Mikro (Faujiah 2020)}

Peningkatan kesejahteraan masyarakat dilakukan oleh lembaga keuangan syariah dengan memberikan pembiayaan dana kebajikan dan melakukan program tanggung jawab sosial. Dana kebajikan atau akad Qardhul hasan dalam Lembaga Keuangan Syariah dikenal dengan akad pinjaman dana kepada nasabah dengan ketentuan bahwa nasabah wajib mengembalikan pokok pinjaman yang diterimanya pada waktu yang telah disepakati baik secara sekaligus maupun cicilan. Prosedur pembiayaan Qardhul Hasan yang diterapkan 21di Lembaga Keuangan Syariah serta bagaimana penyaluran pembiayaan Qardhul Hasan di Lembaga Keuangan Syariah, bertujuan untuk menyempurnakan kewajiban hubungan dengan Allah SWT, hubungan dengan manusia dan hubungan dengan alam sekitar dalam rangka menghasilkan pembangunan ekonomiguna meningkatkan kualitas kehidupan yang lebih baik. Dengan menggunakan metode Kuantitatif melalui teknik analisis, observasi dan dokumentasi untuk memperoleh sebuah kesimpulan. Pada umumnya sumber dana pembiayaan Qardhul Hasan melalui Zakat, Infaq, Shodaqoh yang berasal dari LAZNAS (Lembaga Amil Zakat Nasional) di Lembaga Keuangan Syariah. Penyaluran pembiayaan Qardhul Hasan di Lembaga Keuangan Syariah sudah terlaksana dengan tepat sasaran yaitu pihak yang mendapat pembiayaan Qardhul Hasan ini hanya masyarakat menengah kebawah yang memiliki Usaha Kecil dan Menengah (UKM) kerena dilakukan survei terlebih dahulu mengenai keadaan nasabah sebenarnya, pembiayaan Qardhul Hasan ini sudah sesuai dengan akad Qardh yaitu pembiayaan ini ditunjukan untuk sosial dan tolong menolong serta nasabah hanya wajib mengembalikan pokok pembiayaannya saja tanpa dikenai margin waqaf uang dapat membantu perkembangan bank-bank syariah, khususnya BPR Syariah. Keunggulan dana waqaf, selain bersifat abadi atau jangka panjang, dana waqaf adalah dana termurah yang seharusnya menjadi incaran bank-bank Syariah (bank wakaf mikro).

Perbedaan peneliti sebelumnya dengan peneliti saat ini adalah peneliti terdahulu meneliti Akad Qardhul Hasan Pada Bank Wakaf Mikro, dimana salah keunggulan dana waqaf, selain bersifat abadi atau jangka panjang, dana waqaf adalah dana termurah 
yang seharusnya menjadi incaran bank-bank Syariah (bank wakaf mikro). Sedangkan pada peneliti saat ini akad Qardhul Hasan yang di praktekkan pada lembaga keuangan BMT, dimana sumber dananya masih varian tidak hanya dari sumber wakaf melainkan masih ada dari proses penghimpunan dana masyarakat dalam bentuk tabungan dan dana investasi lainnya.

\section{Analisis Penerapan Pembiayaan Qardhul}

Hasan Berdasarkan PSAK Syariah Pada BMT Al Ittihad Rumbai Pekanbaru (Suryadi and Putri 2018)

Penelitian ini bertujuan menganilisis penerapan pembiayaan Qardhul Hasan berdasarkan PSAK syariah pada BMT al Ittihad Rumbai Pekanbaru. Metode penelitian yang digunakan adalah metode penelitian kualitatif sebagai dasar penulisan bersifat deskriptif analisis. Dengan teknik pengumpulan data yaitu wawancara, mengumpulkan dokumen, serta menggunakan studi pustaka. Hasil penelitian ini menyimpulkan bahwa pelaporan pembiayaan Qardhul Hasan sudah sesuai dengan PSAK Syariah karena dananya berasal dari dana internal Yayasan YKPI sehingga tidak dipisahkan dari laporan neraca melainkan disajikan dalam laporan neraca. Namun pihak BMT tidak memisahkan sumber atau aliran dananya sehingga dapat diasumsikan pembiayaan Qardhul Hasan ini menggunakan dana dari Zakat, Infaq dan Sedekah(ZIS). Penerapan pembiayaan Qardhul Hasan hanya diperuntukkan bagi karyawan dan pegawai saja sehingga jauh dari referensi serta dalil tentang pembiayaan itu sendiri. Kemudian untuk perlakuan akuntansi Qardhul Hasan belum sepenuhnya sesuai dengan PSAK Syariah baik dalam pengakuan dan pengungkapan transaksi.

Perbedaan peneliti sebelumnya dengan peneliti saat ini adalah peneliti terdahulu meneliti penerapan pembiayaan qardhul hasan berdasarkan PSAK syariah pada BMT Al Ittihad Rumbai Pekanbaru, dimana hasil penelitian perlakuan akuntansi Qardhul Hasan belum sepenuhnya sesuai dengan PSAK Syariah baik dalam pengakuan dan pengungkapan transaksi. Sedangkan pada peneliti saat ini akad Qardhul Hasan yang di praktekkan pada Lembaga keuangan BMT Amanah Subang hanya melihat kesesuaian antara teori dengan kondisi praktek yang nyata di Koperasi Amanah Subang tersebut, tidak mengkaji akad Qardhul Hasan sesuai dengan PSAK Syariah baik dari segi pengakuan maupun pengungkapan transaksi.

\section{Akad Qordhul Hasan Sebagai Sarana}

Pelaksanaan CSR Pada Perbankan Syariah (Arief 2012)

Qordhul Hasan adalah kegiatan penyaluran dana dalam bentuk pinjaman kebajikan tanpa imbalan dengan kewajiban pihak peminjam mengembalikan pokok pinjaman secara sekaligus atau cicilan dalam waktu tertentu. Dalam konteks kekinian qardhul hasan sendiri tidak berhenti pada paparan konsep belaka, namun tercermin dalam beberapa aplikasi perekonomian dan telah menjamur di perbankan Syariah. Maka penerapan CSR pada perusahaan dan instansi baik pemerintah dan swasta merupakan wadah dan sarana untuk qardhul hasan diterapkan dengan tujuan sosial yang besumberkan dari infaq, zakat, shadaqoh, denda dan juga sumbangan. Dan keutuhan akad qardhul hasan pun dalam Islam harus berlandaskan sempurnanya rukun, syarat, manfaat, fatwa bahkan jelas akan aplikasinya sehingga terbentuknya system control yang rapi bagi pelaku akad dan ekonom. Selaranya pula pegiat ekonomi melihat qardhul hasan menjadi respon korporat dalam transaksi di perbankan Syariah di era modern ini. 
Perbedaan peneliti sebelumnya dengan peneliti saat ini adalah peneliti terdahulu meneliti Akad Qordhul Hasan Sebagai Sarana Pelaksanaan CSR Pada Perbankan Syariah, artinya akad Qardhul Hasan dijadikan sebagai jembatan jiwa sosial/ tabarru'iyah-nya lembaga perbankan dengan pihak masyarakat. Sedangkan pada peneliti saat ini akad Qardhul Hasan yang di praktekkan pada Lembaga keuangan BMT Amanah Subang hanya melihat kesesuaian antara teori dengan kondisi praktek yang nyata di Koperasi Syariah atau BMT Amanah Subang, bukan sebagai sarana menyalurkan CSR semata.

\section{Evaluasi Non Performing Loan (NPL)}

Pinjaman Qardhul Hasan (Studi Kasus Di

BNI Syariah Cabang Yogyakarta) (Adnan and Furywardhana 2006)

Qardhul-hasan merupakan salah satu produk pembiayaan yang disediakan oleh bank syariah. Berbeda dengan produk pembiayaan lainnya, qardhul-hasan memiliki karakteristik yang unik, antara lain untuk menghibur nasabah yang sangat spesifik yang dapat dikategorikan sebagai kelompok dhuafa. Hasil penelitian menunjukkan bahwa tiga variabel independen (karakteristik dasar pelanggan, referensi, pembayaran) berkorelasi negatif dengan variabel dependen. Namun, faktor tujuan tidak memiliki korelasi yang signifikan. Analisis kualitatif lebih lanjut juga menunjukkan bahwa baik manajemen bank maupun penerima qardhul hasan memiliki persepsi yang kurang tepat terhadap produk qardhul hasan. Pada gilirannya memperburuk NPL Qardhul-hasan.

Perbedaan peneliti sebelumnya dengan peneliti saat ini adalah peneliti terdahulu meneliti Evaluasi Non Performing Loan (NPL) Pinjaman Qardhul Hasan yang dipraktekkan Di BNI Syariah Cabang Yogyakarta, dimana manajemen bank maupun penerima qardhul hasan memiliki persepsi yang kurang tepat terhadap produk qardhul hasan. Pada gilirannya memperburuk NPL Qardhul-hasan. Sedangkan pada peneliti saat ini akad Qardhul Hasan yang di praktekkan pada Lembaga keuangan BMT Amanah Subang hanya melihat kesesuaian antara teori dengan kondisi praktek yang nyata di Koperasi DKM, tidak meneliti lebih jauh terkait evaluasi performa pernyaluran dana atau pinjaman pada BMT Amanah Subang.

9. Qardhul Hasan dalam Persfektif Hukum Islam pada Baitul Maal wa Tamwil (BMT) dan Implementasinya (Muhamad Bisri Mustofa and Mifta Khatul Khoir 2019)

Dalam pelaksanaan Lembaga Keuangan Syariah seperti Baitul Maal wa Tamwil (BMT) terdapat berbagai macam cara penghimpunan dana dan penyaluran dana. Penghimpunan dana dilakukan melalui simpanan wadie ah dan deposito. Sedangkan penyaluran dana dilakukan dengan pembiayaan murabahah, mudharabah musyarakah, rahn (gadai), ijarah, ijarah multijasa dan pembiayaan qardhul hasan. Pembiayaan Qardhul Hasan merupakan orientasi fungsi Lembaga Keuangan Syariah (Baitul Maal Wa Tamwil) sebagai lembaga sosial. Qardhul hasan adalah suatu pinjaman lunak yang diberikan atas dasar kewajiban sosial semata. Dalam hal ini peminjam tidak dituntut untuk mengembalikan apapun kecuali sejumlah yang dipinjamnya. Dalam pembiayaan Qardhul Hasan terdapat rukun dan syarat yaitu pelaku akad yang terdiri dari muqtaridh (peminjam), muqridh (pemberi pinjaman), qardh (dana),shighat yaitu ijab dan qabul kerelaan kedua belah pihak dan dana digunakan untuk sesuatu yang bermanfaat dan halal. Qardhul Hasan merupakan kegiatan untuk mencapai tujuan atau sasaran yang telah ditentukan terlebih dahulu oleh lembaga keuangan syariah yang bersangkutan. Mekanisme penerapan Qardhul Hasan 
semata-mata bertujuan untuk memberikan pertolongan guna memenuhi kebutuhan masyarakat kecil. Dengan demikian dapat diketahui bahwa bentuk peminjaman melalui Qardhul Hasan sudah sesuai dengan prinsip hukum ekonomi syariah, potensi sumber dana Qardhul Hasan ternyata cukup besar apabila dimanfaatkan dan dikelola secara optimal dan implementasinya sangat berguna bagi masyarakat.

Perbedaan peneliti sebelumnya dengan peneliti saat ini adalah peneliti terdahulu meneliti Qardhul Hasan dalam Persfektif Hukum Islam dan Implementasinya yang di praktekkan pada Lembaga Baitul Maal wa Tamwil (BMT). Sedangkan pada peneliti saat ini akad Qardhul Hasan yang di praktekkan pada lembaga keuangan BMT Amanah Subang, dimana secara kelembagaan koperasi ini sudah Syariah kalau melihat dari segi label (nama), tetapi kadang masih ditemukan oknum-oknum berkedokkan Lembaga keuangan Syariah tapi pada operasionalnya tidak mencerminkan Syariah. Begitu pun penelitian saat ini ingin mengkaji dan menganalisis kesesuaian teori dengan praktek dilapangan khususnya di BMT Amanah Subang.

\section{Implementasi Sifat Ta'awun Dalam} Lembaga Keuangan Syariah Melalui Akad Al-Qardh (Rukiah 2019)

Tujuan dari penulisan artikel ini adalah untuk mengetahui konsep Al-qardh dalam lembaga keuangan syariah dari tinjauan fiqh, bagaimana kendala kendala pelaksanaan di lapangan, serta produk- produk apa saja yang memakai akad ini di lembaga keuangan. Metode analisis yang dipakai adalah kajian literatur dan temuan di lapangan. Hasil yang ditemukan adalah bahwa, akad qardh dalam prakteknya, belum maksimal dimanfaatkan lembaga keuangan untuk optimalisasi fungsi sosialnya, dan kurangnya kesadaran nasabah untuk mengembalikan hutang qardh, sebab adanya persepsi nasabah bahwa hutang qardh itu adalah dana kebajikan.

Perbedaan peneliti sebelumnya dengan peneliti saat ini adalah peneliti terdahulu meneliti Implementasi sifat ta'awun dalam lembaga keuangan syariah melalui akad AlQardh, artinya praktek akad Qardhul Hasan dijadikan sarana sifat tolong-menolong antara Lembaga keuangan dengan nasabah atau masyarakat. Sedangkan pada peneliti saat ini akad Qardhul Hasan yang di praktekkan pada lembaga keuangan BMT Amanah Subang, dimana secara kelembagaan koperasi ini sudah Syariah kalau melihat dari segi label (nama), tetapi kadang masih ditemukan oknum-oknum berkedokkan Lembaga keuangan Syariah tapi pada operasionalnya tidak mencerminkan Syariah. Begitu pun penelitian saat ini ingin mengkaji dan menganalisis kesesuaian teori dengan praktek dilapangan khususnya di BMT Amanah Subang.

\section{METODOLOGI PENELITIAN}

Metode Penelitian pada dasarnya merupakan cara ilmiah untuk mendapatkan data dengan tujuan dan kegunaan tertentu dan data yang diperoleh melalui penelitian itu adalah data empiris (teramati) yang mempunyai kriteria tertentu yaitu valid (Sugiyono 2016).

Artinya, data yang diteliti adalah mengenai pembiayaan Qardhul Hasan di BMT AlAmanah Cabang Subang.

1. Jenis dan Sifat penelitian

a. Jenis Penelitian

Dilihat dari jenisnya, penelitian ini termasuk penelitian lapangan (field research) dengan pendekatan deskriptif analisis, yaitu suatu penelitian yang dilakukan sistematis dengan mengangkat data yang ada di lapangan kemudian menganalisisnya dan mendapatkan 
kesimpulan dari penelitian ini (Suharsimi 1995). Penelitian yang dilakukan dalam kehidupan yang sebenarnya. Hasil penelitian ini diperoleh dengan cara mengamati, mencatat, mengumpulkan data dan informasi yang ada dilapangan.

b. Sifat Penelitian

Penelitian ini bersifat deskriptif kualitatif yaitu suatu penelitian yang dilakukan dalam kehidupan sebenarnya. Penelitian deskriptif yaitu suatu uraian sistematis tentang teori dan hasil-hasil penelitian yang relevan dengan variabel yang diteliti (Margono 2005).

\section{HASIL DAN PEMBAHASAN \\ A. Syarat dan Ketentuan Pembiayaan Qardhul Hasan di BMT Al-Amanah Cabang Subang}

Setiap pembiayaan mempunyai syarat dan ketentuan untuk mendapatkan pembiayaan Qardhul Hasan yang terdapat di BMT AlAmanah Cabang Subang, pemohon harus menjadi anggota BMT Al-Amanah terlebih dahulu untuk bisa mendapatkan pembiayaan Qardhul Hasan, sebelum pemohon mendapatkan pembiayaan Qardhul hasan pemohon harus menjadi anggota BMT AlAmanah Cabang Subang, adapun syarat untuk menjadi anggota BMT Al-Amanah Cabang Subang, sebagai berikut:

1. Mengisi formulir aplikasi pembukaan rekening

2. Melampirkan fotocopy KTP / SIM

3. Membayar simpnan pokok Rp. 100.000, dan simpanan wajib Rp. 25.000.

4. Setoran selanjutnya Rp. 25.000 / Bulan

Proses berikutnya dalam pembiayaan Qardhul Hasan ada syarat-syarat yang harus dipenuhi oleh anggota BMT Al-Amanah Cabang Subang adapun persyaratan untuk melakukan pembiayaan Qardhul Hasan, sebagai berikut:
1. Sudah menjadi anggota di BMT AlAmanah Cabang Subang

2. Sudah membayar simpanan pokok dan simpanan wajib

3. Anggota tertib dalam melunasi simpanan pokok dan simpanan wajib bulanan.

4. Anggota tidak bermasalah dalam pembayaran angsuran pembiayaan yang diberikan

5. Anggota sudah tiba pada jatuh tempo pembayaran angsuran

6. Anggota mengalami penurunan usaha.

7. Anggota mengalami usaha nya failed / Bangkrut.

\section{B. Sistem Pembiayaan Akad Qardhul Hasan Di BMT Al-Amanah Cabang Subang}

Hasil analisis Penulis yang diperoleh dari hasil wawancara dengan Bapak Dede Cahya selaku Kepala Cabang BMT AL-Amanah Cabang Subang langkah awal untuk melakukan pembiayaan Qardhul hasan yaitu Anggota datang ke BMT dengan membawa persyaratan serta menjelaskan keperluan mengajukan pembiayaan pertama / awal seperti Murabahah, Mudharabah, Musyarakah, dan Rahn, sebagai contoh akad Murabahah untuk membeli barang dengan sistem jual beli berdasarakan kesepakatan bersama. Proses pencairannya dilakukan setelah pihak BMT melakukan penilaian.

Pencairan dilakukan setelah ditandatanganinya akad pembiayaan dari kedua belah pihak. Setelah itu BMT Al-Amanah menetapkan angsuran bulanan pada pembiayaan tersebut yang telah disepakati oleh anggota dan disanggupi untuk berapa kali angsurannya. Dengan sistem jangka waktu yaitu minimal kurang dari 2 juta, angsurannya maximal 12 kali bayar / I Tahun Proses pembayarᄀan angsuran bisa dilakukan di kantor BMT Al-Amanah Cabang Subang. 
Kendala yang di alami BMT Al-Amanah Cabang Subang pada saat melaksanakan pembiayaan Murabahah adalah gagal bayar atau proses penunggakan cicilan macet. BMT Al-Amanah mempunyai solusi untuk anggota yang tidak bisa membayar angsuran dengan situasi usaha menurun, dengan itu terjadi korvensi akad menjadi Qardhul Hasan, dengan sisa tunggakan yang telah jatuh tempo. Setelah menjadi akad Qardhul Hasan, anggota harus membayar biaya materai dan administrasi, disatukan dengan sisa angsuran anggota. Jadi akad Qardhul Hasan disini digunakan bagi anggota yang mengalami perkonomian macet, usaha menurun, dan failed / bangkrut.

Pembiayaan Qardhul Hasan tidak dilakukan survei kembali, karena survei sudah dilakukan pada awal anggota melakukan pembiayaan sebelumnya diantaranya yaitu pembiayaan Mudharabah, Murabahah, Musyarakah, dan Rahn, karena pembiayaan Qarhdul Hasan ini sifat nya koversi dari akad sebelumnya. Oleh Karena itu pembiayaan Qardhul Hasan memiliki syarat dan ketentuan yang berbeda.

Selanjutnya ada ketegori tertentu terhadap anggota yang membutuhkan kebutuhan mendesak seperti biaya pendidikan, biaya pengobatan, dan sebagainya. BMT AlAmanah menyediakan akad Tawaruk, akad tawaruk adalah transaksi pembelian komoditas antara kedua belah pihak (pembeli dan penjual) dengan harga tangguh, untuk selanjutnya oleh si pembeli dijual kembali ke pembeli yang lain (pihak ketiga) untuk mendapatkan uang tunai, atau dikenal dengan istilah commodity murabahah.

$$
\text { Bagan } 4.1
$$

Flowchart pembiayaan yang di konversi ke akad Qardhul Hasan

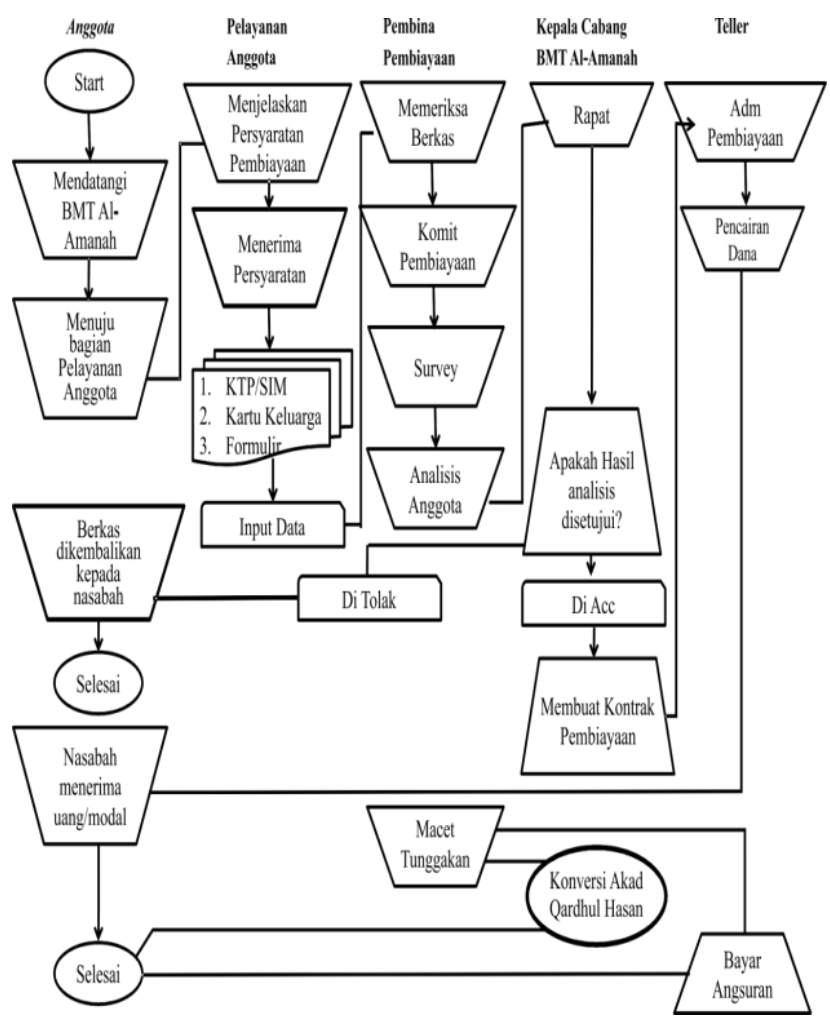

Keterangan :

1. Calon Nasabah datang ke bagian pelayanan BMT Al-Amanah Subang

2. Bagian pelayanan anggota menjelaskan persyaratan pembiayaan di BMT AlAmanah Subang

3. Bagian pelayanan menerima berkas pembiayaan (Formulir, KTP, KK)

4. Bagian pelayanan menginput berkas pengajuan pembiayaan nasabah BMT AlAmanah Subang

5. Pembina pembiayaan memeriksa kelengkapan berkas nasabah BMT AlAmanah Subang

6. Pembina pembiayaan mengkomitekan pengajuan pembiayaan

7. Pembina pembiayaan menugaskan tim survey untuk menganalisis keadaan riil nasabah pembiayaan

8. Kepala Cabang mendiskusikan hasil survey calion nasabah pembiayaan (acc / tolak)

9. Jika pembiayaan di tolak, maka berkas di kembalikan lagi ke bagian Pembina 
pembiayaan, yang selanjutnya di serahkan kembali kepada anggota.

10. Jika pembiayaan di acc, Maka Kepala Cabang menyiapkan kontrak pembiayaan

11. Bagian Teller menyiapkan Slip Administrasi dan Slip pencairan pembiayaan, yang selanjutnya di tanda tangani oleh kedua belah pihak (pihak Nasabah dan BMT Al-Amanah Subang)

12. Nasabah menerima dana pembiayaan

13. Pembina pembiayan akan mendapatkan informasi up to date tentang perkembangan usaha atau kelancaran angsuran nasabah.

14. Jika nasabah tidak mampu bayar angsuran pembiayaan (Pembiayaan macet), maka kepala cabang akan membuat kebijakan terkait konversi akad pembiayaan sebelumnya ke akad Qardh (kontrak pembiayaan baru menggunakan Akad Qardh), besaran angsuran dan jangka waktu disesuaikan dengan kemampuan nasabah

15. Nasabah tinggal membayar angsuran sesuai dengan kemampuannya.

Di BMT Al-Amanah Cabang Subang akad yang bisa dikonversi ke akad Qardhul Hasan yaitu akad Mudharabah, Murabahah, Musyarakah, dan Rahn. Jadi untuk pembiayaan Qardhul Hasan di BMT AlAmanah Cabang Subang terjadi karena anggota mengalami kesulitan untuk membayar sisa tunggakan dari akad sebelumnya.

\section{Manfaat Akad Qardhul Hasan bagi anggota dan pengelola BMT Al- Amanah Cabang Subang}

Manfaat Qardhul hasan bagi anggota dan pengelola yaitu:

1. Bagi anggota yaitu Sangat Membantu anggota yang sedang mengalami kesulitan untuk membayar angsuran dan sebagai sumber pinjaman yang bersifat non komersial / dana talang.

2. Bagi pengelola yaitu Karena pembiayaan Qardhul Hasan bersifat sosial dan tolong menolong maka akan memberikan citra baik bagi BMT Al-Amanah Cabang Subang.

\section{KESIMPULAN}

Berdasarkan hasil dari penelitian penulis yang bersumber dari data-data hasil observasi, wawancara serta dokumentasi sehingga diperoleh hasil seperti yang dikemukakan pada bab sebelumnya dan dapet ditarik kesimpulan bahwa:

1. Syarat dan ketentuan pembiayaan Qardhul Hasan di BMT Al-Amanah Cabang Subang tidak menggunakan jaminan dengan syarat harus menjadi anggota BMT Al-Amanah, serta anggota tidak mampu lagi untuk membayar angsuran pembiayaan akad sebelumnya yang telah jatuh tempo.

2. Sistem Pembiayaan Qardhul Hasan di BMT Al-Amanah Cabang Subang yaitu:

a. Untuk anggota BMT Al-Amanah yang menjadi anggota aktif dengan mempunyai simpanan pokok dan simpanan wajib

b. Untuk anggota yang telah mempunyai pembiayaan, yang telah jatuh tempo, tetapi kesulitan untuk membayar angsuran pembiayaan, maka oleh BMT Al-Amanah di konversi akad menjadi Qardhul Hasan.

3. Manfaat Qardhul hasan bagi anggota dan pengelola yaitu:

a. Bagi anggota yaitu Sangat Membantu anggota yang sedang mengalami kesulitan untuk membayar angsuran dan sebagai sumber pinjaman yang bersifat non komersial / dana talang.

b. Bagi pengelola yaitu Karena pembiayaan Qardhul Hasan bersifat 
sosial dan tolong menolong maka akan memberikan citra baik bagi BMT AlAmanah Cabang Subang.

\section{DAFTAR PUSTAKA}

Administrasi, Fitri Nurjanah Staff. 2019. "Wawancara Tentang Pembiayaan Qardhul Hasan Di BMT Al-Amanah Subang."

Adnan, Muhammad Akhyar, and Firdaus Furywardhana. 2006. "Evaluasi Non Performing Loan (NPL) Pinjaman Qardhul Hasan (Studi Kasus Di BNI Syariah Cabang Yogyakarta)." Jurnal Akutansi Dan Auditing Indonesia 10, no. 2: 155-71.

Amalia, Euis. 2011. "Transformasi NilaiNilai Ekonomi Islam Dalam Mewujudkan Keadilan Distributif Bagi Penguatan Usaha Kecil Mikro Di Indonesia." Al-Iqtishad: Jurnal Ilmu Ekonomi Syariah 3, no. 1.

Antonio, Muhammad Syafi'i. 2001. Bank Syariah Dari Teori Ke Praktik. Jakarta: Gema Insani Press.

Arief, Yoyok Suyoto. 2012. “Akad Qordhul Hasan Sebagai Sarana Pelaksanaan CSR Pada Perbankan Syariah." Ijtihad: Jurnal Hukum Dan Ekonomi Syariah 6, no. 2.

Arumastuti, Agnetia. 2016. "Peran Produk

Pembiayaan Terhadap Kesejahteraan Masyarakat Pada BMT 'Akbar' Polokarto, Sukoharjo.” Universitas Muhammadiyah Surakarta.

Ascarya, Penulis. 2011. Akad Dan Produk Bank Syariah. Jakarta: PT. Grafindo Persada.

BMT Al-Amanah Subang. 2019. "Laporan Rapat Anggota Tahunan(RAT) BMT AlAmanah Cabang Subang." Subang.

Budiman, Farid. 2013. "Karakteristik Akad
Pembiayaan Al-Qardh Sebagai Akad Tabarru'." Yuridika 28, no. 3.

Bukhari, Muhammad bin Isma'il al. n.d. Shohih Bukhari. Juz III. Beirut: Dar al Fikr.

Efendi, Rustam, and Boy Syansul Bakhri. 2018. "Konsep Koperasi Bung Hatta Dalam Perspektif Ekonomi Syariah." $A L$ HIKMAH: Jurnal Agama Dan Ilmu Pengetahuan 15, no. 1.

Enang, Sudrajat. 2010. Al-Qur'an Dan Terjemah. Bandung: PT Madina Raihan Makmur.

Faujiah, Ani. 2020. "Praktek Akad Qardhul Hasan Pada Bank Wakaf Mikro." ACTIVA: Jurnal Ekonomi Syariah 3, no. 1: 72-89.

Hajjaj, Abu Husain Muslim bin Al. n.d. Shahih Muslim. Jilid 1. Bairut: Dar al Fikr.

Ismail. 2017. Perbankan Syariah. Jakarta: Kencana.

Ma'rifahYuliani. 2019. “Konsep Divisi Ekonomi Masjid Berbasis Teknologi Industri 4.0." Jurnal Al Qardh 4, no. 2: 99-114.

Margono, Slamet. 2005. Metodologi Penelitian Pendidikan. Jakarta: Rineka Cipta.

Muhamad Bisri Mustofa, and Mifta Khatul Khoir. 2019. "Qardhul Hasan Dalam Persfektif Hukum Islam Pada Baitul Maal Wa Tamwil (BMT) Dan Implementasinya." At Taajir: Jurnal Ekonomi, Bisnis Dan Keuangan Syariah 1, no. 1 (August): 44-58. https://doi.org/10.47902/attaajir.v1i1.27.

Muhammad. 2005. Bank Sya'riah: Problem Dan Prospek Perkembangan Di Indonesia. Yogyakarta: Graha Ilmu. 
Muhammad, Ridwan. 2004. Manajemen Baitul Maal Wa Tamwil. Yogyakarta: Universitas Islam Indonesia Press.

Muslich, Wardi. 2010. Ahmad Fiqh Muamalat. Jakarta: AMZAH.

Purwadi, M. Imam. 2011. "Qardh Al-Hasan Dalam Perbankan Syariah : Konsep Dan Implementasinya Berdasarkan Prinsip Manfaat Bagi Pemberdayaan Masyarakat." UNISIA: Jurnal Ilmu-Ilmu Sosial 33, no. 74: 141-54.

Qadir, Abdurrahman. 2001. TUraZakat Dalam Dimensi Mahdah Dan Sosial. Jakarta: Raja Grafindo Persada.

Qardhawi, Yusuf. 1993. Fatwa-Fatwa Kontemporer I. Jakarta: Gema Insani Press.

Riswandi, Dedi. 2015. "Pembiayaan Qardul Hasan Di Bank Syariah Mandiri Kota Mataram." Istinbath: Jurnal Hukum Islam IAIN Mataram 14, no. 2: 41843.

Rukiah, Rukiah. 2019. "Implementasi Sifat Ta'awun Dalam Lembaga Keuangan Syariah Melalui Akad Al-Qardh." Studi Multidisipliner: Jurnal Kajian Keislaman 6, no. 1 (October): 87-103. https://doi.org/10.24952/multidisipliner. v6i1.1751.

Solekha, Yasmin Afnan, Alisa Qotrunnada Murdianah, Nofia Sri Lestari, and Rinda Asytuti. 2021. "Baitul Maal Wa Tamwil Sebagai Lembaga Keuangan Mikro Syariah Pemberdaya Ekonomi Umat (Konsep Dan Teori)." Velocity: Journal Of Sharia Finance And Banking 1, no. 1: 44-58.

Sriyana, Jaka, and Fitri Raya. 2013. "Peran BMT Dalam Mengatasi Kemiskinan Di Kabupaten Bantul." INFERENSI: Jurnal Penelitian Sosial Keagamaan 7, no. 1: 29-50.
Subarkah, Andi, Heri Tohari, Muhammad Kafiyanto, Hedi Fajar Rahadian, and Saefudin. 2012. Himpunan Al-Qur'an Dan Terjemah New Cordova. Bandung: Syaamil Quran.

Sugiyono. 2016. Metodologi Penelitian Kuantitatif, Kualitatif Dan $R \& D$. Bandung: Alfabeta.

Suharsimi, Arikunto. 1995. Dasar-Dasar Research. Bandung: Tarsoto.

Sulistyo, Heru, and Abdul Hakim. 2013. "Model Pembiayaan Pedagang Kaki Lima (PKL) Melalui Qardhul Hasan." Riptek 7, no. 1: 39-46.

Suryadi, Nanda, and Yusmila Rani Putri. 2018. "Analisis Penerapan Pembiayaan Qardhul Hasan Berdasarkan Psak Syariah Pada BMT Al Ittihad Rumbai Pekanbaru." Jurnal Tabarru': Islamic Banking and Finance 1, no. 1 (May): 37 50.

https://doi.org/10.25299/jtb.2018.vol1(1) .2043 . 